\title{
TRUDNOŚCI KOMUNIKACYJNE ZAGROŻENIEM DLA WYCHOWANIA RELIGIJNEGO W RODZINIE. ZARYS PROBLEMATYKI
}

Posługa katechetyczna jest sposobem urzeczywistniania się Kościoła jako znaku jedności ${ }^{1}$. Inicjuje i pogłębia rzeczywistość spotkania osoby ludzkiej z Osobami Boskimi. Dlatego też w każdym momencie posługa katechetyczna musi wypełniać zasadę wierności Bogu i człowiekowi ${ }^{2}$ Zasada ta jest szczególnie istotna w kontekście formacji religijnej w rodzinie. Wynika ona z nadrzędnego celu katechezy, jakim jest doprowadzenie do komunii z Jezusem i pogłębienia wiary ${ }^{3}$.

Obowiązek wychowania religijnego wynika już z samej istoty małżeństwa ${ }^{4}$. Współczesny świat niesie wiele różnorakich wyzwań i trudności, które sprawiają, że realizacja tego zadania staje się problematyczna. Paradygmaty pedagogiczne są podważane i próbuje się je zastąpić spontanicznością i okazjonalnością. Ma to także wpływ na sposób przeżywania wiary, zwłaszcza przez dzieci i ludzi młodych. Także procesy związane z komunikacją interpersonalną są poddawane różnorakim sprawdzianom. Rodzi się wiele pytań i wątpliwości, w jaki sposób należy postrzegać i realizować troskę o wychowanie religijne w rzeczywistości rodzinnej.

Celem niniejszego artykułu jest analiza podstawowych trudności związanych $\mathrm{z}$ komunikacją $\mathrm{w}$ kontekście wychowania religijnego w rodzinie. Używając stwierdzenia „wychowanie religijne”, niniejsze opracowanie zakłada wychowanie $\mathrm{w}$ wierze religii katolickiej. Cel ten zostanie zrealizowany poprzez trzy następujące po sobie paragrafy. Pierwszy, dotyczący analizy bazującej na wytycznych Kościoła odnośnie do wychowania religijnego w rodzinie. Drugi ukazuje podstawowe trudności komunikacyjne, z którymi zmaga się współczesna rodzina. Trzeci paragraf to poszukiwanie odpowiedzi i wskazówek $\mathrm{w}$ rozwiązywaniu przedstawionych problemów. Badane zagadnienie stanowi rzeczywistość złożoną i wielopłaszczyznową. Niniejszy artykuł jest zarysowaniem

\footnotetext{
Por. LG 2.

Por. DOK 145

3 Por. DOK 80; PDK 31; P.T. Goliszek, Personalistyczny wymiar katechezy, Lublin 2017.

4 Por. FC 39.
} 
problematyki i może stanowić w przyszłości źródło do dalszych poszukiwań naukowych ${ }^{5}$.

\section{Wychowanie religijne $w$ rodzinie}

W literaturze katechetycznej rodzina jest podstawowym środowiskiem, w którym dokonuje się wzrost i rozwój wiary ${ }^{6}$. Nazywana jest wręcz „Kościołem domowym"7. Wychodząc od ogólnego rozumienia terminu „wychowanie”, można stwierdzić, że poprzez wychowanie religijne należy rozumieć pomoc „udzielaną człowiekowi w realizacji jego człowieczeństwa, w nadaniu życiu człowieka ostatecznego sensu rozumianego na ogół jako zjednoczenie człowieka z Bogiem poprzez praktykowanie miłości bliźniego"8. Współczesna koncepcja wychowania religijnego, które dokonuje się w rodzinie, zawiera założenia pedagogiczne i teologiczne. Realizacja tego zadania jawi się jako trudna, gdyż łączy w sobie świat materialny i nadprzyrodzony ${ }^{9}$.

Koncepcja wychowania religijnego w rozumieniu chrześcijańskim rozwija się od ponad dwóch tysięcy lat i stanowi właściwie podstawę tradycji wychowania europejskiego w ogóle ${ }^{10}$. Celem takiego wychowania jest kształtowanie osoby na wzór Jezusa Chrystusa. Powinno ono zdążać do kształtowania człowieka w kierunku celu ostatecznego, a także uzdalniania do wypełniania dobra społecznego ${ }^{11}$. To na rodzicach ciąży obowiązek, aby troszczyli się o przekazane życie i wspomagali rozwój dziecka zarówno na płaszczyźnie osobowej, intelektualnej, społecznej i duchowej ${ }^{12}$.

$\mathrm{W}$ procesie wychowania religijnego rodzinie przypisuje się funkcje katechetyczne. To właśnie rodzice, poprzez swoje dzieło, wyrażają i urzeczywistniają potrójne posłannictwo Kościoła. Prowadzą dzieci do właściwego pojmowania sensu Boga (posłannictwo prorockie). Uczą oddawania Mu czci (posłannictwo kapłańskie). Kształtują także postawę zdolną do wypełniania przykazania miłości względem bliźniego oraz bycia obecnym we wspólnocie Kościoła (posłannictwo królewskie) ${ }^{13}$.

\footnotetext{
5 Niniejszy artykuł jest owocem projektu badawczego, realizowanego w ramach Instytutu Nauk Teologicznych UKSW. Tytuł projektu to „Katecheza rodzinna wobec współczesnych wyzwań społecznych".

6 Por. LG 11; FC 49; EN 71; DOK 255.

7 Por. DOK 255.

8 J. Kozielecki, Z Bogiem albo bez Boga, Warszawa 1991, s. 24.

9 Por. Z. Trenti, Educazione religiosa, w: Dizionario di scienze dell'educazione, J.M. Prellezo (red.), Roma 2008, s. 394-396.

10 Por. S. Kunowski, Podstawy współczesnej pedagogiki, Warszawa 1993, s. 94.

11 Por. GE 1.

12 Por. tamże 1-3.

13 Por. GE 3; G. Gatti, Katecheza rodzinna, w: Słownik katechetyczny, J. Gevaert (red.), Warszawa 2007, s. 453-457.
} 
Rodzina wypełnia to posłannictwo, wykonując określone funkcje ${ }^{14}$ :

a. symboliczno-objawiającą (budowanie tożsamości chrześcijańskiej) - jest ona związana $z$ istotą rodziny i budowaniem tożsamości chrześcijańskiej. $\mathrm{Na}$ podstawie objawienia rodzina kształtuje młodego człowieka do relacji synowskiej z Bogiem Ojcem, braterskiej z Jezusem Chrystusem oraz przeżywania wspólnoty w Duchu Świętym. Polega również na budowaniu właściwej tożsamości eklezjalnej. Rodzina, dążąc do świętości wszystkich jej członków, sprawia, że „wytwarza się cały zespół międzyosobowych odniesień: oblubieńczość, ojcostwo-macierzyństwo, synostwo, braterstwo, poprzez które każda osoba wchodzi do „rodziny ludzkiej” i do „rodziny Bożej”, którą jest Kościół”15.

b. interpretacyjno-egzystencjalną (budowanie autonomii) - jest ona związana z pluralizmem sytuacji życiowych. Zadaniem rodziców jest wprowadzenie dziecka w świat relacji społeczno-kulturowych, w których konieczne jest podejmowanie decyzji. Proces wychowania, realizując tę funkcję, polega na interpretacji i narracji wydarzeń życia codziennego w świetle prawd objawionych. Rodzice troszczą się o to, że młody człowiek, wchodząc w nowe środowiska i spotykając nowe osoby, odgrywające w jego życiu wpływ wychowawczy, jest gotowy do autonomicznego funkcjonowania. W momencie wchodzenia w dorosłe życie „proces samowychowania w zasadniczej mierze potwierdza to, co dokonało się w dziecku, poprzez wychowanie w rodzinie i w szkole. Nawet przeobrażając się, odchodząc we własnym kierunku, młody człowiek pozostaje nadal w orbicie swych egzystencjalnych korzeni" ${ }^{\prime 16}$.

c. alfabetyzująco-znaczącą (budowanie zdolności komunikacyjnych) - jest ona niezwykle ważna w procesie komunikacji. Polega na nauczeniu młodego człowieka przez rodzinę „,chrześcijańskiego alfabetu”, to znaczy języka wiary, rozumienia podstawowych gestów, znaków, rzeczywistości, tajemnic i postaw. Ma to wpływ na zdolność „p poruszania się” w świecie wiary i duchowości, kształtuje umiejętność komunikacyjną oraz odniesienia prospołeczne. Dzieci poznają „alfabet wiary” pierwotnie poprzez naśladowanie rodziców, z czasem uczą się wykorzystywać język oraz zachowania niewerbalne, poznają nowoczesne narzędzia komunikacyjne. Jak podkreśla V. Satir, „komunikacja jest najpotężniejszym czynnikiem determinującym rodzaj relacji

\footnotetext{
14 Por. tamże, s. 454-455.

15 FC 15.

16 Jan Paweł II, List do rodzin Gratissimam Sane, 16; por. B. Kant, Rodzina - Boży atom: rozważania o rodzinie, Warszawa 1995, s. $47 \mathrm{nn}$.
} 
z innymi ludźmi i własny rozwój”" ${ }^{17}$. Stąd też troska o budowanie zdolności komunikacyjnych wydaje się stanowić kluczowy element wychowania ${ }^{18}$.

d. potwierdzająco-zaświadczającą (budowanie) - jest ona istotna, gdyż potwierdza przekazywane przez rodziców treści. Funkcja ta ma znaczenie w przestrzeni wychowania do wiary, „które powinno się rozpocząć w zaraniu dzieciństwa, dokonuje się już, gdy członkowie każdej poszczególnej rodziny wspomagają się wzajemnie, by wzrastać w wierze przez swoje często milczące, ale wytrwałe świadectwo życia chrześcijańskiego, prowadzonego według Ewangelii wśród codziennych zajęć" ${ }^{\prime 1}$. Dziecko, które doświadcza świadectwa, uczy się bycia świadkiem. Kształtuje to w nim postawę odwagi i umacnia tożsamość wyznawanej wiary. Świadectwo chrześcijańskie w rodzinie domaga się jednak doświadczenia człowieczeństwa. Istotne znaczenie ma spotkanie $z$ dojrzałym człowieczeństwem rodziców oraz innych wychowawców. Można uznać, odwołując się do słów Jana Pawła II, że młody człowiek zostaje „obdarowany człowieczeństwem”20.

Realizacja powyższych funkcji pozwala stwierdzić, że wychowanie religijne w rodzinie opiera się o wychowanie na płaszczyźnie osobowej. Komunikacja na płaszczyźnie nadprzyrodzonej jest możliwa tylko wtedy, kiedy posiada się zdolności komunikacyjne z drugim człowiekiem. Zadania wychowawcze rodziców dotyczą zatem zarówno relacji międzyosobowych, jak i troski o jakość wspólnoty rodzinnej, atmosfery życia codziennego i świadectwa. Od jakości relacji rodzinnych oraz procesów komunikacyjnych zależy zdolność nawiązywania przez dziecko osobowego kontaktu z Bogiem, które później znajduje odzwierciedlenie w modlitwie i życiu sakramentalnym. W konsekwencji ma to wpływ na ukształtowanie się obrazu Boga, odkrycie roli Jezusa Chrystusa, kształtowanie światopoglądu chrześcijańskiego oraz konkretne postawy społeczne ${ }^{21}$.

17 V. Satir, Rodzina. Tu powstaje człowiek, Gdańsk 2002, s. 56.

18 Por. W. Kądziołka, Komunikacja międzyosobowa we współczesnej rodzinie, „Studia Socialia Cracoviensia" 4 (2012) 1 (6), s. 113-125.

19 CT 68; por. GE 3.

20 Jan Paweł II, List do rodzin Gratissimam Sane, 16; por. J. Goleń, Rola świadectwa w rodzinie, „Verbum Vitae” 28(2015), s. 423-458; A. Skreczko, Znaczenie świadectwa wiary rodziców w wychowaniu religijnym dzieci, „Studia Pastoralne” 9 (2013), s. 33-48.

21 Por. Ł. Idem, Proces inicjacji chrześcijańskiej dziecka w rodzinie, „Studia Gdańskie”, 21 (2007), s. 353-375; J. Przybyłowski, Wychowanie chrześcijańskie w rodzinie: poszukiwanie pastoralnych symptomatów, „Warszawskie Studia Pastoralne” 3 (2006), s. 90-113; R. Bibik, Komunikacja interpersonalna w rodzinie i szkole. Porady dla nastolatków i doroslych, Wrocław 2013. 


\section{Współczesne problemy - trudności komunikacyjne}

Od narodzenia aż do śmierci człowiek podlega procesom komunikacyjnym. Przynależność do rodziny jako grupy społecznej daje mu poczucie bezpieczeństwa, wyzwala od strachu, lęku, samotności. Zdolności komunikacyjne gwarantują mu solidarność społeczną oraz realizację podstawowych potrzeb ${ }^{22}$. Wyjątkowe miejsce w strukturze społecznej i duchowej świata zajmuje rodzina. Ostatnie dekady w obliczu stale rosnących wyzwań cywilizacyjnych przynoszą liczne trudności. Kształtowanie kompetencji komunikacyjnych oraz proces wychowania do wiary odkrywają różnorakie przeciwności. Pośród podstawowych utrudnień możemy wymienić:

a. Brak równowagi antropologicznej ${ }^{23}$

Rodzina stanowi pierwsze i naturalne środowisko wychowawcze i kulturowe. Przekazuje i kształtuje podstawową umiejętność rozumienia siebie samego oraz spostrzegania człowieka jako jedności duchowo-materialnej, która jest stworzona przez Boga. Transmisja kulturowa podstawowych paradygmatów antropologicznych we współczesnym świecie została zachwiana. Bezrefleksyjność życia oraz spontaniczność podejmowania decyzji wydają się dalekie od troski o odkrycie swojego powołania.

We współczesnych warunkach wychowawczych osoba przynależy równocześnie do wielu grup społecznych, zarówno tych realnych, jak i funkcjonujących w świecie cyfrowym. Wzrasta liczba „konkurencyjnych” środowisk wychowawczych, nowych systemów wiedzy, norm i wartości, które zmieniają rozumienie osoby, jej godności oraz powołania ${ }^{24}$.

Postawy społeczne, moralne, a przede wszystkim religijne są uzależnione już nie tylko od kształtu życia rodzinnego, ale różnych grup i środowisk. Sieć wpływów społecznych, która kształtuje antropologię, uległa radykalnej zmianie. Już nie tylko rodzice i krewni czy osoby z najbliższego otoczenia mają znaczący wpływ na kształtowanie się świadomości. Obecnie dominującą rolę odgrywa świat medialny, w tym portale i komunikatory społecznościowe, moda, trendy społeczne. Życie ludzkie postrzegane jest często jako gra lub przygoda albo nawet projekt do realizacji. Tożsamość człowieka konstruowana jest w rozproszeniu. Wartości, którymi kieruje się człowiek, są nieprzewidywalne, niepewne i często prowadzą do

22 Por. G. Colombero, Od słów do dialogu, Kraków 2004, s. 43.

23 Por. P. Tomasik, Pedagogika wobec kryzysu wychowania, „Warszawskie Studia Teologiczne” 11 (1998), s. 287-318.

24 Por. W. Sroczyński, Środowisko wychowawcze - zarys problemu, „Kultura i Edukacja” 2 (2008), s. 26-47; M. Filipowicz, Rodzina jako pierwsze środowisko wychowawcze. Zadania i ideał wychowawczy - z perspektywy nauczania Kościoła, „, Łódzkie Studia Teologiczne” 26 (2017) 1, s. 127-146. 
zagubienia. Spór o koncepcję pedagogiczną wydaje się jałową kłótnią o bezstresowe wychowanie. Rodzice, którzy do tej pory pełnili funkcję pierwszych wychowawców, stają się bezradni ${ }^{25}$. Młody człowiek odrzuca autorytet rodzica jako wychowawcy i nauczyciela wiary. To miejsce zajmują często idole, celebryci, influencerzy ${ }^{26}$.

Kryzys lub wręcz upadek autorytetu rodzica, zniekształcona antropologia oraz nieproporcjonalny wpływ świata cybernetycznego na proces wychowania owocują zanikiem więzi rodzinnych, brakiem umiejętności porozumiewania się oraz propagowaniem modelu „nakazowego" w wychowaniu. To wszystko nie sprzyja budowaniu postawy dialogu ${ }^{27}$.

\section{b. Niedojrzałość emocjonalna}

Każde dziecko ma prawo do własnej odrębności, tożsamości oraz godności. Stwierdzenie to wydaje się oczywiste, jednak w przestrzeni wychowania rodzinnego okazuje się trudne do realizacji. Osiągnięcie dojrzałości emocjonalnej wymaga czasu, ale również równowagi edukacyjnej w rodzinie. Najpierw niezbędne jest poznanie, zrozumienie własnych emocji. Jest to warunek konieczny, aby nad nimi panować i w odpowiedni sposób je wyrażać ${ }^{28}$. Bazą do rozwoju człowieka, jak uważa A. Brzezińska, jest naturalny zegar biologiczny. Decyduje on „w znacznym stopniu o tempie i rytmie procesu dojrzewania, a także o osiągnięciu funkcjonalnej dojrzałości przez ośrodkowy układ nerwowy, zawiadujący działaniem naszego organizmu i odpowiadający za kontakt $\mathrm{z}$ otoczeniem" ${ }^{\text {"29 }}$.

M. Ryś, mówiąc o dojrzałej osobowości, zdolnej do umiejętnego wyrażania uczuć i emocji, wymienia cztery czynniki wspierające rozwój osobisty. Są to: autentyzm i troska o własny rozwój osób wychowujących (rodziców i wychowawców), prawidłowe zaspokajanie potrzeb (więzi emocjonalne i bezpieczeństwo), pomoc w budzeniu odpowiedzialności za własny rozwój osobowy oraz oddziaływanie osobistym przykładem ${ }^{30}$.

Realizacja wyżej wymienionych czynników wspierających rozwój emocjonalny wydaje się zachwiana. Ludzie młodzi często powielają błędy związane z emocjami, których doświadczali w swoich rodzinach. Osoby niedojrzałe emocjonalnie podatne są na konflikty, nie potrafią przyjąć krytyki, w sposób wyolbrzymiony

\footnotetext{
25 Por. E. Walewander, Postmodernizm a pedagogia katolicka, Toruń 2011; B. Śliwerski, Nauki o wychowaniu wobec wyzwań postmodernizmu, „Chowanna” 1 (2003), s. 9-18.

26 Por. E. Węgrzyn-Jonek, Rozważania o wychowaniu. W poszukiwaniu teoretycznych podstaw koncepcji wychowawczej szkoły, Warszawa 2014.

${ }^{27}$ Por. M. Śnieżyński, Quo vadis polska rodzino?, w: K. Denek (red.), Edukacja jutra. Edukacja ustawiczna, Sosnowiec 2013, s. 227-242.

28 Por. DOK 239.

29 A. Brzezińska, Psychologiczne portrety człowieka, Gdańsk 2005, s. 24.

30 Por. M. Ryś, Wspieranie rozwoju osobowego w rodzinie, w: M. Ryś (red.), W trosce o rodzinę. W poszukiwaniu prawdy, dobra i piękna, Warszawa 2007, s. 25-40.
} 
przeżywają stres, próbują podporządkować otoczenie do siebie, a nie odwrotnie, okazują nadmierną wrażliwość i niepewność siebie. W konsekwencji prowadzi to do kształtowania osobowości introwertycznej, niezdolnej do komunikacji społecznej. Na przestrzeni życia religijnego są mało aktywne lub wręcz całkowicie bierne z racji na małą umiejętność współpracy i budowania wspólnoty. Unikają wszelkiej odpowiedzialności i są niezdolne do podejmowania szczerych relacji osobowych. W konsekwencji, postawa emocjonalna takich osób staje się powierzchowna i nadmiernie pretensjonalna ${ }^{31}$. Rodzi to także skrajne zagrożenia przeżywania wiary w sposób całkowicie pozbawiony uczuć i emocji lub też w sposób jedynie afektywny i daleki od rzeczywistości ${ }^{32}$.

c. Odmienne postrzeganie rzeczywistości - różnice językowe

Każde działanie katechetyczne, które prowadzi do poznawania Boga i umacniania wiary, jest aktem komunikacji. Troska o autentyczne przekazanie treści objawienia Bożego nakazuje również zachowanie wierności człowiekowi. Stwarza to jednak duże wyzwanie pedagogiczne w sytuacji, gdzie zachodzi zauważalna transgresja pokoleniowa. Zjawisko to jest widoczne w różnym postrzeganiu tych samych rzeczywistości związanych z wiarą. Różnice pokoleniowe wywołują odmienne wyobrażenia religijne. Dotyczy to przestrzeni wiedzy, wartości, moralności, obyczajów, idei oraz wzorców zachowań, które w całości tworzą formę życia religijnego ${ }^{33}$.

Komunikacja międzypokoleniowa napotyka liczne trudności w rodzinie, która jest głównym nośnikiem i przekazicielem zasad rozumienia języka werbalnego i niewerbalnego. Komunikacja staje się czynnikiem określającym jakość relacji. To, jak człowiek da sobie radę ze swoim życiem, jak odnajdzie jego sens, w jaki sposób zwiąże się z Bogiem - wszystko to w dużym stopniu zależy od jego umiejętności komunikacyjnych ${ }^{34}$. Istotnym zatem wydaje się pytanie, czy rodzina, która wychowuje nowe pokolenia, jest zdolna do tego, aby uwzględnić aspekt zmian kulturowych. Często dochodzi do konfliktu pokoleń lub „wojny domowej”. Nie chodzi tutaj o historyczny spór pokoleń (klasyków i romantyków), ale o konsekwencje kulturowe i religijne. Różnice dzielące pokolenia prowadzą do przeciwstawień „my” i „oni”, to znaczy „swój” i „obcy”. Ten podział wyraża poczucie braku tożsamości i obecności we wspólnocie kulturowej lub religijnej. Ma to również przełożenie

\footnotetext{
31 Por. KKK 1767-1768; M. Polak, Wychowywać nasze emocje, w: http://bit.ly/sk16-19 [dostęp 9.07.2020].

32 Por. DOK 255; W. Osial, Potrzeba i znaczenie doświadczenia wiary w procesie wychowania religijnego. Analiza wybranych aspektów katechetyczno-pastoralnych, „Pedagogia Christiana” 2 (2008) 22, s. 43-55.

${ }^{33}$ Por. E. Karmolińska-Jagodzik, Komunikacja międzypokoleniowa - rozważania wokół różnic kulturowych, „Studia Edukacyjne” 21 (2012), s. 191-210.

34 Por. tamże, s. 199.
} 
na brak zrozumienia języka komunikacji i pogłębiający się dystans między pokoleniami. Religia i wiara stają się często symbolem niezgody i podziału. Próba podjęcia dialogu o treści religijnej często prowadzi do niezrozumienia i przynosi wręcz odwrotny skutek ${ }^{35}$.

d. Stosunek ja-realnego do ja-idealnego - wzorzec moralny

Jednym $z$ istotnych zadań wychowania religijnego jest także przekazanie wartości moralnych. Tradycyjna rodzina miała często cechy instytucji i kierowała się sformalizowanymi wzorcami zachowań i relacji międzyludzkich (na przykład między rodzicami a dziećmi). Współcześnie rodzina staje się raczej wspólnotą opartą o więzi emocjonalne. Zmiana przebiega według wektora prowadzącego od stosunków rzeczowych do stosunków osobistych. Zmienia się także oczekiwanie co do jakości życia religijnego. Obecnie dominuje również przekonanie, że życie rodzinne ma dawać pełnię satysfakcji, nie wychowuje ono do służby i ofiary ${ }^{36}$.

Wychowanie moralne we współczesnych rodzinach zostało zredukowane do realizacji przejścia od ja-realnego do ja-idealnego. Istnieje jednak problem braku odpowiedniego wzorca. Dziecko, obserwując najbliższe otoczenie, nie znajduje tam przykładu zachowań moralnych, a jedynie słyszy ciągłe napomnienia i wskazania. Rodzice nie przeżywają swojej wiary w sposób integralny, a przez to nie są wiarygodnymi świadkami Chrystusa ${ }^{37}$. W konsekwencji prowadzi to do postawy, w której to rodzice samych siebie czynią ostatecznym autorytetem zachowań moralnych. Nie wskazują swoim nauczaniem i przykładem na Jezusa Chrystusa oraz nie prowadzą do osobowej relacji z Nim. Wiara, którą prezentują rodzice, staje się wtedy jedynie koncepcją życiową, a nie autentyczną decyzją pójścia za Chrystusem, która angażuje całego człowieka ${ }^{38}$. Jest to szczególnie ważne w momencie, kiedy dziecko jest $\mathrm{w}$ wieku wczesnoszkolnym i ulega przeobrażeniom związanym $\mathrm{z}$ intelektualizacją emocji, rozwojem myślenia abstrakcyjnego i samodzielnego poszukiwania decyzji moralnych. W wieku dojrzewania prowadzi to z kolei do konfliktów pomiędzy pokoleniami na tle wartościowania zjawisk oraz osób. W życiu dorosłym może z kolei owocować całkowitym odwróceniem się od rodziców oraz rzeczywistości religijnej. Okazuje się wtedy, że w latach dorastania i kształtowania osobowości praktykowanie wiary było jedynie obowiązkiem oraz wypełnieniem polecenia rodziców, a nie samodzielną decyzją. Troska o przekazanie wartości kolejnym pokoleniom

\footnotetext{
35 Por. M. Kita, Style komunikacji międzypokoleniowej, w: B. Witosz (red.), Style konwersacyjne, Katowice 2006, s. 80-89.

36 Por. J. Mariański, Wychowanie moralne w rodzinie, „Ius Matrimoniale” 8 (2003) 14, s. 193-220.

37 Por. Z. Marek, Wychować do wiary, Kraków 1996, s. 108.

38 Por. J. Nagórny, Opcja fundamentalna w praktyce życia chrześcijańskiego, w: B. Jurczyk (red.), Przesłanie moralne Kościoła, Lublin 1994, s. 75-98.
} 
powinna więc implikować określone wewnętrzne motywacje chrystocentryczne oraz twórczy sposób ich przeżywania ${ }^{39}$.

Analizując zatem podstawowe współczesne trudności komunikacyjne w rodzinie, można wyznaczyć wspólny mianownik dla wszystkich wyżej opisanych. Elementem łączącym, który wydaje się największą bolączką współczesnych rodzin i utrudniającym skuteczne komunikowanie się, jest szeroko rozumiany brak świadectwa wiary. To niewystarczający poziom autentyczności działań podejmowanych przez rodziców w procesach wychowawczych. To także brak konsekwencji, umiejętności przyznawania się do błędów pedagogicznych, umiarkowana zdolność do okazywania uczuć i emocji, a nawet przemoc. Chrześcijański wzorzec postępowania personalistycznego rodziców, którzy są jednocześnie wzorcem osobowym i nosicielem wartości, wydaje się trudny do osiągnięcia ${ }^{40}$.

\section{Propozycje rozwiązań}

Dokonując analizy powyższych trudności, posługując się metodą teologii pastoralnej, poszukującą nowych koncepcji i rozwiązań, należy wskazać konkretne próby i pomysły zmierzające do poprawy sytuacji. Czymś niepodważalnym wydaje się troska rodziców o właściwy poziom komunikacji w rodzinach. Także zobowiązanie podjęte na chrzcie świętym odnośnie do wychowania w wierze wydaje się czymś istotnym. To wszystko sprawia, że rodzina dla dziecka powinna być pierwszą szkołą wiary. Właśnie w tej wspólnocie dziecko powinno uczyć się prowadzić twórczy dialog z człowiekiem i Bogiem. Zadaniem rodziców jest uwrażliwienie dzieci na znalezienie właściwej równowagi pomiędzy troską o świat materialny a rozwojem życia duchowego. Powyższy cel urzeczywistnia się poprzez następujące zadania:

a. Budowanie relacji osobowej - czas - budowanie relacji nadprzyrodzonej

Rodzice są pierwszymi partnerami i nauczycielami relacji młodego człowieka. Współczesna pedagogika wyróżnia trzy modele wychowania: autokratyczny, liberalny oraz demokratyczny ${ }^{41}$. Każdy z nich ma kluczowe znaczenie dla budowania relacji rodzice-dzieci. Mogą oddziaływać one w sposób pozytywny lub negatywny. Żaden z nich jednak nie występuje w czystej postaci. Postawa rodziców zwykle jest

\footnotetext{
39 Por. J. Gajda, Wychować do prawdy, Lublin 1995, s. 13nn.; A. Skreczko, Znaczenie świadectwa wiary rodziców, dz. cyt., s. 36-39.

40 Por. R. Murawski, Wiara a wychowanie, „Colloquia Theologica Ottoniana” 1 (2014), s. 59-73.

${ }^{41}$ Por. J Kurasz, Znaczenie rodziny w wychowaniu dziecka, „Journal of Clinical Healthcare” 1/2016, s. 1-8; A. de Tchorzewski, Wstęp do teorii wychowania, Kraków 2018, s. 102-110; B. Ostafińska-Molik, E. Wysocka, Style wychowania $w$ rodzinie pochodzenia w percepcji młodzieży gimnazjalnej $i$ ich znaczenie rozwojowe - próba teoretycznej i empirycznej egzemplifikacji, „Przegląd Pedagogiczny” 2 (2014), s. 213-234.
} 
bliższa któremuś z wymienionych. Jak pokazuje praktyka polskiej rzeczywistości pedagogicznej, najczęściej występującym jest styl autokratyczny. Oparty jest on o ponadprzeciętny autorytet rodziców i akcentuje dyscyplinę, władzę, odebranie przywilejów, stosowanie rygorów, narzucanie własnych poglądów ${ }^{42}$. Karność i przesadna dyscyplina nie są jednak dobrym środowiskiem do budowania dialogu i dojrzałej relacji osobowej. Także liberalne podejście jest przeakcentowaniem wolności. Jedynie wychowanie w duchu demokratycznym wydaje się korzystnym wyborem. Pozwala ono bowiem dorastającemu człowiekowi kształtować umiejętność budowania relacji międzyludzkich. Styl ten jest najbardziej pozytywny w perspektywie budowania relacji rodzice-dzieci. Opiera się na podmiotowym traktowaniu obu stron. Styl demokratyczny, który posiada duży zakres autonomii, ale jednocześnie jest wyrazem zainteresowania i troski, uczy podejmowania trudnych decyzji, buduje relację partnerską. Rodzice nadal pozostają w funkcji wychowawcy i pełnią rolę „kierowniczą”. Czynią jednak dziecko aktywnym członkiem rodziny, które nie tylko realizuje swoje prawa, ale jest wychowywane do podejmowania obowiązków. Chociaż wprowadzenie w życie tego modelu wychowawczego nie jest łatwe, jest to jedyna droga gwarantująca rozwój zdrowej relacji rodzice-dzieci. Dziecko, które dorasta w atmosferze akceptacji, współdziałania, rozumnej swobody i odpowiedzialności posiada dobry fundament do budowania od najmłodszych lat relacji nadprzyrodzonej (wiary).

Dziecko, postrzegane jako autonomiczna jednostka, rozwija się w dialogu z otoczeniem. Rodzice, dostosowując wymagania do etapu rozwoju, w sposób pozytywny wprowadzają dziecko w świat relacji społecznych i religijnych ${ }^{43}$.

b. Troska o formację ludzką - umiejętność wyrażania swoich emocji - dojrzałość osobowa - dojrzałość w wierze

Środowisko rodzinne jest pierwszym miejscem wychowania w życiu dziecka, które kształtuje jego emocje i uczucia. Wywiera także wpływ na postawy, kształtowanie wartości, norm i wybór wzorców postępowania. Rola rodziny w tej kwestii nie ogranicza się jedynie do wczesnych lat życia dziecka. Nie kończy się nawet w momencie, kiedy osoba staje się samodzielna lub tworzy własną rodzinę ${ }^{44}$. To właśnie w środowisku rodzinnym kształtują się podstawowe cechy osobowości. Człowiek odkrywa swoją tożsamość, powołanie i w ten sposób dojrzewa do roli wychowawcy.

Zadaniem rodziców jest troska o to, aby dziecko rozwijało się nie tylko w sposób biologiczny i psychiczny, ale także duchowy, to znaczy mają zatroszczyć się

\footnotetext{
${ }^{42}$ Por. Z. Frączek, B. Lulek, Wybrane problemy pedagogiki rodziny, Rzeszów 2010, s. 64-65.

43 Por. M. Dyrdół, Relacje rodzice-dziecko i ich prawne konteksty, „Wychowanie w Rodzinie” 10 (2014) 2, s. 281-296.

${ }^{44}$ Por. L. Dyczewski, Rodzina twórca i przekazicielem kultury, Lublin 2003, s. 9.
} 
oni o jego potrzeby elementarne, ale i o potrzeby wyższe ${ }^{45}$. W takim kontekście wychowanie może być rozumiane jako służba dziecku. W świetle teologii można stwierdzić, że jest to współudział rodziców w dziele stwórczym Boga ${ }^{46}$. Należy również pamiętać, że ostatecznym wzorcem w wychowaniu moralnym ma być osoba Jezusa Chrystusa. Zwłaszcza w świetle relatywizmu moralnego wyznaczenie niepodważalnego autorytetu gwarantuje właściwy rozwój moralny, oparty o poznanie intelektualne i religijne ${ }^{47}$.

Istotne jest, aby w świadomości rodziców dominowała postawa wychowania podmiotowego. Założenie takie wyklucza manipulowanie drugim człowiekiem. Rodzice na etapie kształtowania potrzeb wiary nie przymuszają dziecka do jej przyjęcia, ale troszczą się o wychowanie do wiary, stosowne do poziomu rozwoju intelektualnego i emocjonalnego. Podmiotowa relacja do dziecka oznacza ze strony rodziców troskę o poczucie bezpieczeństwa, godności ludzkiej, autentyczność relacji, poczucie bliskości z bliskimi, brak frustracji i lęku, a także wychowanie w kierunku postrzegania świata w sposób pozytywny ${ }^{48}$. Taki model wychowawczy skupia się także na potrzebie miłości, samorealizacji, uznania i szacunku, kontaktu społecznego, przynależności. Rodzice są w stanie zaspokoić wszystkie te potrzeby w stopniu znacznie pełniejszym niż jakiekolwiek inne środowisko ${ }^{49}$.

\section{c. Kompetencje komunikacyjne}

Wiele zakłóceń w kwestii wychowania i kształtowania osobowości wprowadza obecnie świat Internetu. Stąd też zadaniem rodziców jest krytyczna ocena i selekcja doboru środków społecznego przekazu. Nie sposób całkowicie odizolować dziecko od świata medialnego, jednak czymś koniecznym jest wprowadzanie stopniowych ograniczeń na poszczególnych etapach rozwoju. Chodzi o to, aby rodzice ukształtowali w dziecku umiejętność selektywnego i odpowiedzianego korzystania z mediów, zwłaszcza społecznościowych. To rodzice powinni być pierwszymi, którzy kształtują nawyki, zainteresowania i preferencje, a nie świat cybernetyczny. $\mathrm{W}$ świetle wyzwań komunikacyjnych istotnym elementem wychowawczym jest także troska rodziców o to, aby relacje osobowe uprzedzały relacje świata cyfrowego, troska o wizerunek realny była większa niż budowanie wizerunku medialnego. Jak podkreśla Jan Paweł II, na styku rzeczywistości rodziny i świata medialnego konieczne jest zachowanie trzech podstawowych zasad: formacja, uczestnictwo

\footnotetext{
45 Por. J. Wilk, Pedagogika rodziny, Lublin 2016, s. 148.

46 Por. KKK 372, 1657, 2232, 2366, 2378.

47 Por. M. Kluz, Wychowanie chrześcijańskie w rodzinie w dobie permisywizmu moralnego, „Śląskie Studia Historyczno-Teologiczne" 40/2 (2007), s. 364-374.

48 Por. J. Wilk, Pedagogika rodziny, dz. cyt., s. 119-124.

49 Por. tamże, s. 148-153.
} 
i dialog ${ }^{50}$. Bez prawidłowej formacji ludzkiej członkowie rodziny mogą stać się jedynie użytkownikami Internetu, którzy żyją obok siebie, ale pozbawieni są całkowicie relacji opartych o emocje i uczucia ${ }^{51}$.

Na skutek ekspansywnego rozwoju najnowszych technologii komunikacyjnych przed rodzicami staje ważne zadanie. Powinni oni nauczyć dziecko, iż świat cybernetyczny jest przestrzenią służącą nie tylko zabawie i rozrywce, ale także nauce. Nie jest to jedynie środowisko destrukcyjne, ale może być miejscem służącym rozwojowi intelektualnemu, a nawet pracy $^{52}$. Należy pamiętać, że „środki społecznego przekazu, które niezmiernie poszerzają zakres słuchania Słowa Bożego, mogą pomóc młodym ludziom $\mathrm{w}$ realizowaniu - poprzez wolny i odpowiedzialny wybór - ich osobistego powołania jako ludzi i chrześcijan, przez co przygotowują się do tego, aby być budowniczymi i protagonistami społeczeństwa jutra" ${ }^{53}$.

d. Wsparcie ze strony parafii - postulat katechezy dorosłych - grupy wsparcia

Obecnie funkcjonujący system społeczny oferuje rodzinie wiele różnych sposobów wsparcia, poczynając od ekonomicznego, aż do psychologicznego. Takiego wsparcia rodzina mogłaby oczekiwać w przestrzeni edukacji religijnej. Istnieje jednak pewna rozbieżność pomiędzy dokumentami Kościoła, które jednoznacznie stwierdzają potrzebę troski o podstawową komórkę społeczną, jaką jest rodzina, a praktyką widoczną w polskim modelu duszpasterskim. R. Chałupniak $w$ jednym ze swoich artykułów użył precyzyjnego sformułowania odnośnie do nauczania wypływającego z dokumentów kościelnych: „Nie ma katechezy bez rodziny, nie ma rodziny bez katechezy"54.

W obliczu swoistego kryzysu więzi społecznych wspólnota Kościoła powinno dołożyć wszelkich starań, aby wspierać proces wychowawczy w rodzinie. Magna carta nauczania katolickiego na temat rodziny, czyli adhortacja Familiaris consortio, stwierdza: „Rodzina, założona i ożywiana przez miłość, jest wspólnotą osób: mężczyzny i kobiety jako małżonków, rodziców, dzieci i krewnych. Pierwszym jej zadaniem jest wierne przeżywanie rzeczywistości komunii w ciągłym działaniu na rzecz rozwijania prawdziwej wspólnoty osób. (...) Miłość pomiędzy mężczyzną

50 Por. Jan Paweł II, List Apostolski Szybki rozwój, nr 11.

${ }_{51}$ Por. FC 26; E. Osewska, Komunikacja wiary w rodzinie wobec wyzwań Internetu, „Studia nad Rodziną" 17/2 (2013) 33, s. 197-213; G. Grochowski, Kościół na temat katechetycznego wykorzystania Internetu, „Katecheta” 2 (2003), s. 10-18.

52 Por. A. Kozłowska, Oddziaływanie mass mediów, Warszawa 2006, s.159nn; D. Lewczuk, W jaki sposób telewizja i Internet kształtuje mózg? Aktualny problem wychowawczy u dzieci, „Studia Kulturowo-Edukacyjne" 10 (2015) 1, s. 53-68.

${ }^{53}$ Jan Paweł II, Komunikacja społeczna w służbie chrześcijańskiej promocji młodzieży, Orędzie na 19. Światowy Dzień Środków Społecznego Przekazu 1985 r., 1.

54 R. Chałupniak, Katecheza rodzinna - współczesne wyzwania i realizacje, „Matrimonio et familiae” 2016, s. 145-166. 
i kobietą w małżeństwie, i w formie pochodnej i rozszerzonej, miłość pomiędzy członkami tej samej rodziny - pomiędzy rodzicami i dziećmi, pomiędzy braćmi i siostrami, pomiędzy krewnymi i domownikami - jest ożywiana i podtrzymywana przez wewnętrzny, nieustający dynamizm, prowadzący rodzinę do coraz głębszej i mocniejszej komunii, która jest fundamentem i zasadą wspólnoty małżeńskiej i rodzinnej” ${ }^{\prime 5}$.

Bazując na powyższym sformułowaniu, można dojść do wniosku, że wspólnota Kościoła powinna dołożyć wszelkich starań, aby rodzina odzwierciedlała nadprzyrodzony charakter relacji. Aby zrealizować to zadanie, istnieje potrzeba uaktywnienia odpowiednich grup i wspólnot parafialnych. To także paląca potrzeba katechezy dorosłych. Wzajemne dzielenie się życiem, problemami, a także wsparcie na płaszczyźnie ludzkiej i duchowej mogłyby stanowić wydatną pomoc w rozwoju wspólnot rodzinnych. Warto w tym miejscu przytoczyć i promować także konkretne inicjatywy, związane z działalnością wspólnot, takich jak Domowy Kościół, Ruch Światło-Życie, Ekipy Notre-Dame, Wspólnoty Rodzin Emaus, Wspólnoty Rodzin Arka, różnego rodzaju grup promujących katechezę rodzinną. Należałoby również dołożyć starań, aby podnieść jakość istniejących już katechez dla rodziców, które przygotowują do sakramentu chrztu, Eucharystii czy bierzmowania ich dzieci. Odrębną, a zarazem bardzo obszerną przestrzenią już istniejącą w polskiej rzeczywistości duszpasterskiej, są tzw. kursy przygotowujące do sakramentu małżeństwa ${ }^{56}$.

Wszystkie wyżej wymienione formy katechezy rodzin winny skupić się na udzieleniu wsparcia rodzicom, aby odkryli i realizowali oni posłannictwo nauczycieli wiary (katechetów) względem swoich dzieci. Należy wyzbywać się przy tym wszelkich uprzedzeń do funkcji katechetycznych rodziny, uwzględniając nawet pewne braki wiedzy religijnej i zdolności metodologicznych. Przy odpowiedniej ilości czasu to rodzice nadal pozostają najlepszymi wychowawcami wiary. Wszelkie niedoskonałości mogą być uzupełnione miłością i troską rodzicielską ${ }^{57}$.

W myśl powszechnie powtarzanej zasady, że Chrystus nauczał dorosłych, a błogosławił dzieci, należałoby także zintensyfikować wszelkie wysiłki w kierunku katechezy rodziców - w ramach katechezy dorosłych. Bez skutecznej i równoległej katechezy rodziców wszelkie starania związane z katechezą dzieci i młodzieży czy szkolną lekcją religii mogą przynosić niewielki efekt w przestrzeni formacji życia chrześcijańskiego ${ }^{58}$.

\footnotetext{
55 FC 18.

56 Por. G. Pyżlak, Katecheza rodzinna i jej wpływ na przygotowanie do życia małżeńskiego i rodzinnego, „Roczniki Pastoralno-Katechetyczne” 3/58 (2011), s. 413-427.

57 Por. ChL 34; CT 68; DOK 227, 255; PDK 128.

58 Por. M. Chmielewski, Katecheza rodzinna w kontekście wspótczesnych uwarunkowań społeczno-eklezjalnych, w: A. Tomkiewicz, W. Wieczorek (red.), Rodzina jako Kościół domowy, Lublin 2010, s. 305-321; A. Czaja, Rodzina jako Kościół domowy, w: J. Gorbaniuk, B. Parysiewicz (red.), Rodzina wobec wspótczesnych wyzwań społeczno-kulturowych, Lublin 2009, s. 131-140.
} 


\section{Zakończenie}

Zarysowany powyżej obraz rzeczywistości nie jest tragiczny. Stanowi wyzwanie i zadanie. Można w tym momencie odnieść się do eseju Y. Lamberta, wydanego w 1993 roku, który poświęcony jest wzajemnej relacji młodych i chrześcijaństwa ${ }^{59}$. Nowe pokolenie jest tam określane mianem „wielkiego wyzwania” dla Kościoła. Rzeczywiście, także dzisiaj ludzie młodzi stanowią swoisty test dla wspólnoty Kościoła. Dzieje się tak zarówno wtedy, gdy „odchodzą, trzaskając drzwiami, jak i wtedy, gdy zostają, lecz oczekują nowego sposobu bycia w Kościele, takiego, w którym oni sami mogą być bohaterami, a nie zwykłymi statystami" 60 .

Jak można wnioskować, na podstawie powyższych rozważań, proces komunikacji dostarcza wielu wyzwań współczesnym rodzinom, pośród nich zostały wyróżnione: brak równowagi antropologicznej, niedojrzałość emocjonalna, różnice językowe i pokoleniowe oraz trudności w wychowaniu moralnym. To wszystko nie powinno jednak przerażać, a stanowić kluczowy punkt w refleksji nad współczesnym modelem katechezy rodzinnej. Odnosząc się do eseju Y. Lamberta, zadaniem wspólnoty Kościoła jest troska, aby w przyszłości osoby, które dorastają w rodzinach, były zdolne do praktykowania i przekazywania wiary w sposób dojrzały. Służyć temu mogą troska duszpasterska o właściwe relacje osobowe na płaszczyźnie ludzkiej i nadprzyrodzonej, kształtowanie kompetencji komunikacyjnych w świecie realnym i cybernetycznym. Fundamentem wydaje się właściwa formacja ludzka. Rodzice podołają wszystkim tym wyzwaniom jedynie wtedy, kiedy otrzymają odpowiednie wsparcie od wspólnoty Kościoła.

Podsumowaniem końcowym do wszystkich powyższych stwierdzeń mogą być słowa Benedykta XVI. Należy je odczytać nie tylko w świetle postulatu, ale przede wszystkim zobowiązania: „Z tego wszystkiego wypływa oczywisty wniosek: rodzina i Kościól, a mówiąc konkretnie, parafie i inne rodzaje wspólnot kościelnych są powołane do jak najściślejszej współpracy w realizacji tego podstawowego zadania, w którym łączą się nierozdzielnie formacja osoby i przekaz wiary"61.

\section{Streszczenie}

Celem opracowania jest ukazanie trudności komunikacyjnych, które stanowią zagrożenie dla wychowania religijnego $\mathrm{w}$ rodzinie. Studium tematu na podstawie literatury, dokumentów nauczania Kościoła oraz opracowań pozwoliło na sformułowanie postulatów związanych z właściwą formacją ludzką, potrzebą kształtowania kompetencji

\footnotetext{
59 Por. Y. Lambert, Les jeunes et le christianisme: le grand défi, w: N. Gallimard (red.), Le Débat, 3 (1993) 75, s. 60-76.

60 G. Borghi, Wiara w czasach Facebooka, Częstochowa 2011, s. 7.

${ }^{61}$ Benedykt XVI, Rodzina chrześcijańska wspólnota wychowania i wiary - Do uczestników Kongresu Diecezji Rzymskiej, w: http://bit.ly/sk16-20 [dostęp 11.07.2020].
} 
komunikacyjnych w świecie realnym i cybernetycznym. Analiza tematu wskazuje także na potrzebę permanentnej katechezy dorosłych i rodzinnej.

Słowa kluczowe: katecheza rodzinna, trudności komunikacyjne, wiara, rodzina.

\section{COMMUNICATION DIFFICULTIES AS A THREAT TO RELIGIOUS EDUCATION IN THE FAMILY. OUTLINE OF THE PROBLEMS}

\section{Summary}

The aim of the study is to show the communication difficulties that pose a threat to religious education in the family. The study of the topic, on the basis of literature, Church teaching documents and studies, allowed for the formulation of postulates: the necessity of proper human formation, the need to shape communication competences in the real and cybernetic world. The analysis of the topic also shows the need for permanent adult and family catechesis.

Keywords: family catechesis, communication difficulties, faith, family.

\section{Bibliografia}

\section{Nauczanie Kościoła}

Benedykt XVI, Rodzina chrześcijańska wspólnota wychowania i wiary - Do uczestników Kongresu Diecezji Rzymskiej, w: https://opoka.org.pl/biblioteka/W/WP/benedykt_xvi/ przemowienia/rodzina_06062005.html, [dostęp 11.07.2020].

Jan Paweł II, Adhortacja apostolska Catechesi tradendae (16.10.1979) (= CT). Jan Paweł II, Adhortacja apostolska Christifideles laici (30.12.1988) (= ChL). Jan Paweł II, Adhortacja apostolska Familiaris consortio (22.11.1981) (= FC). Jan Paweł II, Komunikacja społeczna w stużbie chrześcijańskiej promocji młodzieży, Orędzie na 19. Światowy Dzień Środków Społecznego Przekazu 1985 r.

Jan Paweł II, List do rodzin Gratissimam Sane (2.02.1994).

Jan Paweł II, List Apostolski Szybki rozwój (24.01.2005).

Katechizm Kościoła Katolickiego (11.10.1992) (= KKK).

Konferencja Episkopatu Polski, Dyrektorium Katechetyczne Kościoła Katolickiego w Polsce, Warszawa 2001 (= PDK).

Kongregacja ds. Duchowieństwa, Dyrektorium ogólne o katechizacji (15.08.1997) (= DOK).

Sobór Watykański II, Deklaracja o Wychowaniu Gravissimum educationis (28.10.1965) (= GE).

Sobór Watykański II, Konstytucja dogmatyczna o Kościele Lumen gentium (21.11.1964) (= LG).

\section{Literatura tematu}

Bibik R., Komunikacja interpersonalna $w$ rodzinie i szkole. Porady dla nastolatków i dorostych, Wrocław 2013.

Borghi G., Wiara w czasach Facebooka, Częstochowa 2011. 
Brzezińska A., Psychologiczne portrety człowieka, Gdańsk 2005.

Chałupniak R., Katecheza rodzinna - współczesne wyzwania i realizacje, Matrimonio et familiae 2016, s. 145-166.

Chmielewski M., Katecheza rodzinna w kontekście wspótczesnych uwarunkowań społeczno-eklezjalnych, w: A. Tomkiewicz, W. Wieczorek (red.), Rodzina jako Kościót domowy, Lublin 2010, s. 305-321.

Colombero G., Od słów do dialogu, Kraków 2004.

Czaja A., Rodzina jako Kościót domowy, w: J. Gorbaniuk, B. Parysiewicz (red.), Rodzina wobec współczesnych wyzwań społeczno-kulturowych, Lublin 2009, s. 131-140.

De Tchorzewski A., Wstęp do teorii wychowania, Kraków 2018.

Dyczewski L., Rodzina twórca i przekazicielem kultury, Lublin 2003.

Dyrdół M., Relacje rodzice-dziecko i ich prawne konteksty, „Wychowanie w Rodzinie” 10 (2014) 2, s. 281-296.

Filipowicz M., Rodzina jako pierwsze środowisko wychowawcze. Zadania i ideał wychowawczy - z perspektywy nauczania Kościoła, „Łódzkie Studia Teologiczne” 26 (2017) 1, s. 127-146.

Frączek Z., Lulek B., Wybrane problemy pedagogiki rodziny, Rzeszów 2010, s. 64-65.

Gajda J., Wychować do prawdy, Lublin 1995.

Gatti G., Katecheza rodzinna, w: Stownik katechetyczny, J. Gevaert (red.), Warszawa 2007, s. 453-457.

Goleń J., Rola świadectwa w rodzinie, „Verbum Vitae” 28 (2015), s. 423-458.

Goliszek P.T., Personalistyczny wymiar katechezy, Lublin 2017.

Grochowski G., Kościół na temat katechetycznego wykorzystania Internetu, „Katecheta” 2(2003), s. 10-18.

Idem Ł., Proces inicjacji chrześcijańskiej dziecka w rodzinie, „Studia Gdańskie” 21 (2007), s. 353-375.

Kant B., Rodzina - Boży atom: rozważania o rodzinie, Warszawa 1995.

Karmolińska-Jagodzik E., Komunikacja międzypokoleniowa - rozważania wokół różnic kulturowych, „Studia Edukacyjne” 21 (2012), s. 191-210.

Kądziołka W., Komunikacja międzyosobowa we wspótczesnej rodzinie, „Studia Socialia Cracoviensia" 4 (2012) 1 (6), s. 113-125.

Kita M., Style komunikacji międzypokoleniowej, w: B. Witosz (red.), Style konwersacyjne, Katowice 2006, s. 80-89.

Kluz M., Wychowanie chrześcijańskie w rodzinie w dobie permisywizmu moralnego, „Śląskie Studia Historyczno-Teologiczne" 40/2 (2007), s. 364-374.

Kozielecki J., Z Bogiem albo bez Boga, Warszawa 1991.

Kozłowska A., Oddziaływanie mass mediów, Warszawa 2006.

Kunowski S., Podstawy wspótczesnej pedagogiki, Warszawa 1993.

Kurasz J., Znaczenie rodziny w wychowaniu dziecka, „Journal of Clinical Healthcare” 1/2016, s. 1-8.

Lambert Y., Les jeunes et le christianisme: le grand défi, w: N. Gallimard (ed.), Le Débat, 3(1993) 75, s. 60-76. 
Lewczuk D., W jaki sposób telewizja i Internet ksztattuje mózg? Aktualny problem wychowawczy u dzieci, „Studia Kulturowo-Edukacyjne” 10 (2015) 1, s. 53-68.

Marek Z., Wychować do wiary, Kraków 1996.

Mariański J., Wychowanie moralne w rodzinie, „Ius Matrimoniale” 8 (2003) 14, s. 193-220.

Murawski R., Wiara a wychowanie, „Colloquia Theologica Ottoniana” 1(2014), s. 59-73.

Nagórny J., Opcja fundamentalna w praktyce życia chrześcijańskiego, w: B. Jurczyk (red.), Przesłanie moralne Kościoła, Lublin 1994, s. 75-98.

Osewska E., Komunikacja wiary w rodzinie wobec wyzwań Internetu, „Studia nad Rodziną” 17/2 (2013) 33, s. 197-213.

Osial W., Potrzeba i znaczenie doświadczenia wiary w procesie wychowania religijnego. Analiza wybranych aspektów katechetyczno-pastoralnych, „Pedagogia Christiana” 2 (2008) 22, s. 43-55.

Ostafińska-Molik B., Wysocka E., Style wychowania w rodzinie pochodzenia w percepcji młodzieży gimnazjalnej i ich znaczenie rozwojowe - próba teoretycznej i empirycznej egzemplifikacji, „Przegląd Pedagogiczny” 2 (2014), s. 213-234.

Polak M., Wychowywać nasze emocje, w: https://opoka.org.pl/biblioteka/M/MR/petrus_2016_b_jest_02.html [dostęp 9.07.2020].

Przybyłowski J., Wychowanie chrześcijańskie w rodzinie: poszukiwanie pastoralnych symptomatów, „Warszawskie Studia Pastoralne” 3 (2006), s. 90-113.

Pyżlak G., Katecheza rodzinna i jej wplyw na przygotowanie do życia małżeńskiego i rodzinnego, „Roczniki Pastoralno-Katechetyczne” 3/58 (2011), s. 413-427.

Ryś M., Wspieranie rozwoju osobowego w rodzinie, w: M. Ryś (red.), $W$ trosce o rodzinę. W poszukiwaniu prawdy, dobra i piękna, Warszawa 2007, s. 25-40.

Satir V., Rodzina. Tu powstaje człowiek, Gdańsk 2002.

Skreczko A., Znaczenie świadectwa wiary rodziców w wychowaniu religijnym dzieci, „Studia Pastoralne" 9 (2013), s. 33-48.

Sroczyński W., Środowisko wychowawcze - zarys problemu, „Kultura i Edukacja” 2 (2008), s. 26-47.

Śliwerski B., Nauki o wychowaniu wobec wyzwań postmodernizmu, „Chowanna” 1 (2003), s. 9-18.

Śnieżyński M., Quo vadis polska rodzino?, w: K. Denek (red.), Edukacja jutra. Edukacja ustawiczna, Sosnowiec 2013, s. 227-242.

Tomasik P., Pedagogika wobec kryzysu wychowania, „Warszawskie Studia Teologiczne” 11 (1998), s. 287-318.

Trenti Z., Educazione religiosa, w: Dizionario di scienze dell'educazione, J.M. Prellezo (red.), Roma 2008, s. 394-396.

Walewander E., Postmodernizm a pedagogia katolicka, Toruń 2011.

Węgrzyn-Jonek E., Rozważania o wychowaniu. W poszukiwaniu teoretycznych podstaw koncepcji wychowawczej szkoty, Warszawa 2014.

Wilk J., Pedagogika rodziny, Lublin 2016. 


\section{O autorze}

ks. Tomasz KOPICZKO - prezbiter diecezji ełckiej, doktor nauk teologicznych, pracownik naukowo-dydaktyczny Uniwersytetu Kardynała Stefana Wyszyńskiego w Warszawie oraz WSD w Ełku, członek Stowarzyszenia Katechetyków Polskich oraz Towarzystwa Naukowego Franciszka Salezego. Zakres swoich zainteresowań badawczych koncentruje wokół tematów związanych z nową ewangelizacją, teologią katechezy, eklezjologią i nowymi środkami komunikacji. 